\title{
PENGARUH STRATEGI PEMBELAJARAN PENINGKATAN KEMAMPUAN BERPIKIR (SPPKB) TERHADAP KEMAMPUAN BERPIKIR KRITIS BIOLOGI PESERTA DIDIK KELAS XI SMA AL-KAUTSAR BANDAR LAMPUNG
}

\author{
${ }^{1}$ Yessy Velina, ${ }^{2}$ Wiwit Nurhasanah ${ }^{3},{ }^{4}$ Zulhannan \\ ${ }^{1,2,3}$ Universitas Islam Negeri Raden Intan Lampung .Jl. H Endro Suratmin \\ Sukarame-Bandar Lampung (0721)70326): wiwitnurhasanah@yahoo.com
}

Diterima : 07 Agustus 2017. Disetujui: 15 Desember 2017. Dipublikasikan: 29 Desember 2017

\begin{abstract}
Abstrak
Pelaksanaan pembelajaran Biologi di kelas XI SMA Al-Kautsar Bandar Lampung kurang melatih dan membiasakan peserta didik untuk berpikir kritis. Hal tersebut menyebabkan kemampuan berpikir kritis biologi yang dimiliki peserta didik masih rendah. Berkenaan dengan masalah tersebut, maka penulis tertarik untuk melakukan penelitian di SMA Al-Kautsar Bandar Lampung pada kelas XI semester genap Tahun Ajaran 2015/2016 untuk mengetahui apakah terdapat pengaruh strategi pembelajaran peningkatan kemampuan berpikir (SPPKB) terhadap kemampuan berpikir kritis biologi peserta didik.

Penelitian ini merupakan penelitian quasy experimental design dengan rancangan posttest only control design. Populasi penelitian ini adalah peserta didik kelas XI SMA Al-Kautsar Bandar Lampung. Sampel yang digunakan sebanyak 2 kelas yang dipilih dengan teknik acak kelas, yaitu kelas XI IPA 1 sebagai kelas eksperimen dan kelas XI IPA 4 sebagai kelas kontrol. Teknik pengumpulan data dengan tes berbentuk uraian, wawancara dan dokumentasi. Analisis data yang digunakan adalah uji-t.

Berdasarkan hasil analisis data dan pengujian hipotesis yang telah dilakukan maka dapat disimpulkan bahwa terdapat pengaruh yang signifikan strategi pembelajaran peningkatan kemampuan berpikir (SPPKB) terhadap kemampuan berpikir kritis biologi peserta didik kelas XI di SMA Al-Kautsar Bandar Lampung. Hal ini dapat dilihat dari perhitungan menggunakan rumus Polled Varians menunjukkan bahwa wng $>t_{\text {tabel }}$ yaitu, 6,115>1,671. Sehingga $\mathrm{H} 0$ ditolak dan $\mathrm{H}_{1}$ diterima.
\end{abstract}

Kata Kunci : Strategi pembelajaran peningkatan kemampuan berpikir (SPPKB) Kemampuan berpikir kritis biologi, Sistem reproduksi manusia.

\begin{abstract}
Implementation of Biology learning in class XI SMA Al-Kautsar Bandar Lampung less to train and familiarize learners to think critically. This causes critical thinking skills possessed biological learners still low. With regard to the problem, the authors are interested in doing research in SMA Al-Kautsar Bandar Lampung in class XI Academic
\end{abstract}


Year 2015/2016 second semester to determine whether there is influence learning strategy for improving the ability to think (SPPKB) the ability to think critically biology students.

This study is quasy experimental design with draft posttest only control design. The study population was the students of class XI SMA Al-Kautsar Bandar Lampung. Samples are 2 classes selected by random technique classes, classes that used as the experiment is the class XI IPA 1 and class XI IPA 4 as the control class. Data collection techniques used are descriptions shaped test, interviews and documentation. Analysis of the data used is the t-test.

Based on the results of data analysis and hypothesis testing has been done it can be concluded that there is significant influence learning strategy for improving the ability to think (SPPKB) the ability to think critically biology class XI students in SMA Al-Kautsar Bandar Lampung. It can be seen from the calculation using the formula polled variance showed that thitung > ttabel, 6.115>1.671. So that $\mathrm{H} 0$ and $\mathrm{H} 1$ accepted.

Key Words: Learning strategy for improving the ability to think (SPPKB), critical thinking skills, the human reproductive system.

\section{PENDAHULUAN}

Pendidikan memiliki tanggung jawab dalam mewujudkan sumber daya manusia yang berkualitas terutama mempersiapkan peserta didik sebagai penerus pembangunan masa depan. Peningkatan kualitas pembelajaran harus dilaksanakan seiring perkembangan IPTEK. Peningkatan tersebut dapat dilaksanakan dengan menerapkan pembelajaran peningkatan berpikir. Pada dasarnya pembelajaran berpikir dapat dengan mudah dilakukan. Namun, kondisi pembelajaran di kebanyakan sekolah belum mendukung untuk terlaksananya pembelajaran kemampuan berpikir yang efektif.

Beberapa kendala yang terjadi adalah penggunaan strategi pembelajaran yang tidak sesuai dengan materi pembelajaran. Pembelajaran di sekolah masih berfokus pada guru (teacher centered) dan peserta didik kurang didorong untuk mengembangkan kemampuan berpikirnya. Pengembangan kemampuan berpikir kritis penting bagi peserta didik. Berpikir kritis menggunakan dasar berpikir menganalisis dan kemampuan memahami asumsi. Menurut Liliasari setiap 
manusia memiliki potensi untuk tumbuh dan berkembang menjadi pemikir yang kritis karena sesungguhnya kegiatan berpikir memiliki hubungan dengan pola pengelolaan diri yang ada pada setiap makhluk di alam termasuk manusia sendiri. (Liliasari, 2013:7)

Saat ini proses pembelajaran dengan memfokuskan perkembangan kemampuan berpikir peserta didik belum terlaksana dengan baik. Melalui observasi di SMA Al-Kautsar Bandar Lampung, diperoleh data awal kemampuan berpikir kritis melalui tes menggunakan soal uraian materi sistem regulasi masih rendah. Kurang ditekankannya strategi pembelajaran peningkatan kemampuan berpikir di SMA Al-Kautsar Bandar Lampung mengakibatkan peserta didik belum memiliki kemampuan berpikir kritis yang maksimal dan perlu dikembangkan.

Berdasarkan pada masalah tersebut, maka peneliti tertarik untuk menggunakan strategi pembelajaran peningkatan kemampuan berpikir (SPPKB) yang mampu mengembangkan gagasan-gagasan berdasarkan pengetahuan dasar dan pengalaman peserta didik, agar dapat mengembangkan kemampuan berpikir kritis. SPPKB merupakan strategi pembelajaran yang menekankan kepada kemampuan berpikir peserta didik, yang bertumpu kepada pengembangan kemampuan berpikir melalui telaah fakta-fakta atau pengalaman sebagai bahan untuk memecahkan masalah yang diajukan. (Anisa, 2013:101)

SPPKB mempunyai 6 tahapan pembelajaran, yaitu: 1) tahap orientasi, 2) tahap pelacakan, 3) tahap konfrontasi, 4) tahap inkuiri, 5) tahap akomodasi, 6) tahap transfer. SPPKB di bangun dalam suasana tanya jawab yang santai namun efektif, oleh karena itu guru dituntut untuk dapat meningkat kan kemampuan 
bertanya untuk melacak, memancing, ber tanya induktif deduktif, serta mengembangkan pertanyaan terbuka dan tertutup. Pertanyaan yang menuntun proses berpikir siswa akan membantu siswa menemukan jawaban dari persoalan yang dihadapi. (Wina Sanjaya, 2006:234-236)

Tujuan penelitian yang ingin dicapai dalam penelitian ini adalah untuk mengetahui apakah terdapat pengaruh atau tidak dari penerapan strategi pembelajaran peningkatan kemampuan berpikir (SPPKB) terhadap kemampuan berpikir kritis biologi peserta didik kelas XI SMA Al-Kautsar Bandar Lampung. Penelitian ini memiliki manfaat bagi guru, dapat dijadikan salah satu alternatif strategi pembelajaran untuk mengembangkan kemampuan berpikir kritis biologi peserta didik dan bagi peneliti lain lain penelitian ini dapat dijadikan acuan untuk penelitian selanjutnya.

\section{METODE PENELITIAN}

Variabel penelitian ini terdiri dari dua variabel, yaitu variabel bebas dan variabel terikat. Variabel bebas dalam penelitian yaitu strategi pembelajaran peningkatan kemampuan berpikir (SPPKB) dan variabel terikat yaitu kemampuan berpikir kritis biologi peserta didik. Metode penelitian yang digunakan adalah penelitian eksperimen. Desain penelitian yang digunakan adalah quasy experimental design dalam bentuk Posttest Only Control Design. Populasi pada penelitian ini adalah seluruh peserta didik pada kelas XI SMA Al-Kautsar Bandar Lampung Tahun Pelajaran 2015/2016 dengan jumlah 143 siswa yang tebagi dalam 4 kelas yaitu terdiri dari kelas XI IPA 1 - XI IPA 4. Sampel yang digunakan sebanyak 2 kelas yang dipilih dengan teknik acak kelas (random 
sampling), yaitu kelas XI IPA 1 sebagai kelas eksperimen menggunakan strategi pembelajaran peningkatan kemampuan berpikir (SPPKB) dan kelas XI IPA 4 sebagai kelas control menggunakan strategi konvensional. Teknik pengumpulan data yang digunakan adalah tes berbentuk uraian untuk mengukur kemampuan berpikir kritis biologi berdasarkan indikator berpikir kritis, wawancara dan dokumentasi. Analisis data menggunakan prasyarat uji-t dengan uji normalitas menggunakan Uji Kolmogorov Smirnov dan homogenitas menggunakan Uji test of homogenity of varience, uji hipotesis menggunakan uji-t Independen t-test.

\section{HASIL PENELITIAN DAN PEMBAHASAN}

Berdasarkan penelitian yang telah dilakukan di SMA Al-Kautsar Bandar Lampung, untuk mengetahui pengaruh penerapan strategi pembelajaran peningkatan kemampuan berpikir (SPPKB) terhadap kemampuan berpikir kritis biologi peserta didik pada materi sistem reproduksi pada manusia. Diperoleh data amatan nilai kemampuan berpikir kritis biologi kelas eksperimen dan kelas kontrol sebagai berikut :

Tabel 1. Rangkuman Data Nilai Kemampuan Berpikir Kritis Biologi Kelas Eksperimen dan Kelas Kontrol

\begin{tabular}{|c|c|c|c|c|c|c|c|c|}
\hline \multirow{2}{*}{ Kelas } & \multirow{2}{*}{$\begin{array}{l}\text { Nilai } \\
\text { Ideal }\end{array}$} & \multirow{2}{*}{ Xmaks } & \multirow{2}{*}{ Xmin } & \multicolumn{3}{|c|}{ Ukuran Tendensi Sentral } & \multicolumn{2}{|c|}{$\begin{array}{l}\text { Ukuran } \\
\text { Dispersi }\end{array}$} \\
\hline & & & & $\mathbf{X}$ & Me & Mo & $\mathbf{J}$ & $\mathbf{S}$ \\
\hline 'ksperimen & 100 & 100 & 57 & 78,656 & 78,5 & 73, dan 87 . & 43 & 12,2 \\
\hline Kontrol & 100 & 83 & 23 & 60,794 & 61,5 & 63 & 60 & 12 \\
\hline
\end{tabular}

Berdasarkan Tabel 1. diketahui bahwa terdapat perbedaan nilai rata-rata kemampuan berpikir kritis biologi peserta didik antara kelas eksperimen dan kelas 
kontrol. Kelas eksperimen memiliki rata-rata kemampuan berpikir kritis biologi lebih tinggi dari pada nilai rata-rata kelas kontrol. Data tersebut dapat dipresentasikan berdasarkan hasil data amatan nilai kemampuan berpikir kritis biologi kelas eksperimen dan kelas kontrol seperti pada tabel berikut :

Tabel 2. Presentase Nilai Kemampuan Berpikir Kritis Biologi Peserta Didik Kelas XI SMA Al-Kautsar Bandar Lampung

\begin{tabular}{|c|c|c|c|c|c|c|c|}
\hline No & $\begin{array}{c}\text { Interval } \\
\text { Nilai }\end{array}$ & $\begin{array}{c}\text { Kelas } \\
\text { Eksperimen }\end{array}$ & Presentase & No & $\begin{array}{c}\text { Interval } \\
\text { Nilai }\end{array}$ & $\begin{array}{c}\text { Kelas } \\
\text { Kontrol }\end{array}$ & Presentase \\
\hline 1 & $91-100$ & 6 & $40,62 \%$ & 1 & 91-100 & - & $5,13 \%$ \\
\hline 2 & $81-90$ & 7 & Sangat Kritis & 2 & $81-90$ & 2 & Sangat Kritis \\
\hline 3 & $71-80$ & 10 & $53,13 \%$ & 3 & $71-80$ & 5 & $46,15 \%$ \\
\hline 4 & $61-70$ & 7 & Kritis & 4 & $61-70$ & 13 & Kritis \\
\hline 5 & $51-60$ & 2 & $6,25 \%$ & 5 & $51-60$ & 11 & $46,16 \%$ \\
\hline 6 & $41-50$ & - & Cukup Kritis & 6 & $41-50$ & 7 & Cukup Kritis \\
\hline 7 & $31-40$ & - & $0 \%$ & 7 & $31-40$ & - & $0 \%$ \\
\hline 8 & $21-30$ & - & $\begin{array}{c}\text { Kurang } \\
\text { Kritis }\end{array}$ & 8 & $21-30$ & - & $\begin{array}{c}\text { Kurang } \\
\text { Kritis }\end{array}$ \\
\hline 9 & $11-20$ & - & $0 \%$ & 9 & $11-20$ & 1 & $2,56 \%$ \\
\hline 10 & $1-10$ & - & Tidak Kritis & 10 & $1-10$ & - & Tidak Kritis \\
\hline \multicolumn{2}{|c|}{ Jumlah } & 32 & $100 \%$ & & Jumlah & 39 & $100 \%$ \\
\hline
\end{tabular}

Berdasarkan data tabel 2. di atas pada kelas eksperimen terlihat bahwa terdapat 40,62 \% siswa sangat kritis, 53,13 \% siswa kritis, dan 16,25 \% siswa cukup kritis. Tidak ada siswa yang kurang kritis, dan tidak kritis. Sedangkan pada kelas kontrol terdapat 5,13\% siswa sangat kritis, 46,15\% siswa kritis, 46,16\% siswa cukup kritis, dan 2,56 \% siswa yang tidak kritis. Artinya kemampuan berpikir kritis biologi peserta didik kelas XI SMA Al-Kautsar Bandar Lampung pada materi sistem reproduksi pada kelas eksperimen lebih tinggi saat diterapkan 
strategi pembelajaran peningkatan kemampuan berpikir (SPPKB) dari pada kelas kontrol dengan strategi pembelajaran konvensional.

Sebelum dilakukan uji hipotesis, data di uji normalitas dengan Kolmogorov Smirnov, dan uji homogenitas dengan uji test of homogenity of varience. Hasil perhitungan diperoleh data sebagai berikut :

Tabel 3. Hasil Uji Normalitas

\begin{tabular}{|c|c|c|c|c|}
\hline No & Kelompok & Sig. & $\begin{array}{l}\text { Kriteria nilai } \\
\quad \text { Sig. }>\alpha\end{array}$ & $\begin{array}{c}\text { Kesimpulan } \\
\text { Sig. }>0,05 \\
\text { (berdistribusi } \\
\text { normal) }\end{array}$ \\
\hline $\begin{array}{l}1 \\
2\end{array}$ & $\begin{array}{c}\text { Eksperimen } \\
\text { Kontrol }\end{array}$ & $\begin{array}{l}\mathbf{0 , 7 7} \\
\mathbf{0 , 9 3}\end{array}$ & 0,005 & $\begin{array}{c}\text { Berdistribusi } \\
\text { normal }\end{array}$ \\
\hline
\end{tabular}

Berdasarkan Tabel 3. dari hasil data uji normalitas dengan bantuan program SPSS 16.0 terlihat probabilitas output Kolmogorov Smirnov untuk kelas eksperimen dan kelas kontrol adalah 0,77 dan 0,93 sedangkan $\alpha=(0,05)$. Karena nilai Asymp.Sig. $>\alpha$ maka $\mathrm{H}_{0}$ diterima atau kedua data berdistribusi normal.

Tabel 4. Hasil Uji Homogenitas

\begin{tabular}{cccc}
\hline No & Kelompok & Sig. & $\begin{array}{c}\text { Kesimpulan } \\
\text { Sig. }>\boldsymbol{\alpha} \mathbf{0 , 0 5} \\
\text { (homogen) }\end{array}$ \\
\hline 1 & Eksperimen & $\mathbf{0 , 0 6}$ & Homogen \\
\hline
\end{tabular}

Berdasarkan Tabel 4. diatas, diperoleh pada test of homogenity of varience nilai Sig. > 0,05, yaitu 0,06 > 0,05 untuk kelas eksperimen, dan 0,60>0,05 untuk kelas kontrol. Maka dapat disimpulkan karena nilai Asymp.Sig. $>\alpha$ maka $\mathrm{H}_{0}$ diterima atau kedua data posttest kemampuan berpikir kritis baik dikelas eksperimen maupun di kelas kontrol. Secara keseluruhan berasal dari data yang sama (homogen). Kemudian data di uji hipotesis dengan rumus Polled Varians. 
Hasil uji statistik untuk nilai strategi pembelajaran peningkatan kemampuan berpikir (SPPKB) diambil dari posttest kemampuan berpikir kritis dapat dilihat pada tabel berikut :

Tabel 5. Uji t Hipotesis Kemampuan Berpikir Kritis Biologi

\begin{tabular}{cccc}
\hline Kelas & $\mathbf{t}_{\text {hitung }}$ & $\mathbf{t}_{\text {tabel }}$ & Kesimpulan \\
\hline $\begin{array}{c}\text { Eksperimen dan } \\
\text { Kontrol }\end{array}$ & $\mathbf{6 , 1 1 5}$ & $\mathbf{1 , 6 7 1}$ & $\begin{array}{c}\mathbf{H}_{\mathbf{0}} \text { ditolak dan } \\
\mathbf{H}_{\mathbf{1}} \text { diterima }\end{array}$ \\
\hline
\end{tabular}

Berdasarkan perhitungan pada tabel 4.8 di atas, perhitungan dengan rumus Polled Varians menunjukkan bahwa ${ }_{\text {ang }}>t_{\text {tabel }} \quad$ yaitu, 6,115 $>1,671$ maka $\mathrm{H}_{0}$ ditolak dan $\mathrm{H}_{1}$ diterima, artinya terdapat pengaruh signifikan strategi pembelajaran peningkatan kemampuan berpikir (SPPKB) terhadap kemampuan berpikir kritis biologi peserta didik kelas XI SMA Al-Kautsar Bandar Lampung.

Keberhasilan pembelajaran pada kelas eksperimen dengan menggunakan SPPKB lebih baik dibandingkan dengan penerapan strategi pembelajaran konvensional pada kelas kontrol. Pada kelas kontrol pembelajaran berpusat pada guru (teacher centered) karena materi pembelajaran ditransformasikan secara langsung oleh guru kepada peserta didik. Sedangkan peserta didik hanya menerima secara pasif dengan mendengarkan, menyimak, dan mencatat apa yang disampaikan oleh guru. Sementara tidak semua peserta didik memiliki keterampilan yang sama dalam hal tersebut. Sehingga menyebabkan kemampuan peserta didik dalam menuangkan ide dan pemikiran masih terbatas.

Pembelajaran menggunakan strategi konvensional, peserta didik ditempatkan sebagai objek belajar yang berperan sebagai penerima informasi secara pasif, pembelajaran bersifat teoritis dan abstrak, perilaku dibangun atas 
kebiasaan, kemampuan diperoleh melalui latihan-latihan, tujuan akhir adalah penguasaan materi pembelajaran, tindakan atau perilaku individu didasarkan oleh faktor dari luar dirinya, misalnya individu tidak melakukan sesuatu disebabkan takut hukuman, pengetahuan dikonstruksi oleh orang lain, serta keberhasilan pembelajaran biasanya hanya diukur dari tes. Faktor-faktor tersebut yang menjadikan kemampuan berpikir kritis kurang baik dan kurang terlatih pada kelas kontrol.

Dengan melaksanakan SPPKB, peserta didik dapat secara aktif terlibat dalam pembelajaran dan berpusat pada siswa (student centered) artinya peserta didik ditempatkan sebagai subjek belajar. Dalam proses pembelajaran memungkinkan peserta didik untuk mengembangkan pengetahuan, kemampuan, dan keterampilan secara penuh dalam suasana belajar yang terbuka dan demokratis. Dimana, para peserta didik tersebut akan berpikir bersama untuk menggambarkan dan meyakinkan bahwa tiap orang mengetahui jawaban tersebut, dan sesuai dengan pengalaman dan fenomena yang ada sesuai dengan teori pembelajaran. Peserta didik memiliki kemampuan berpikir kritis baik pada kelas eksperimen karena pengembangan kemampuan pesertadidik secara aktif menjawab pertanyaan-pertanyaan berupa pertanyaan berpikir kritis dari guru dan terlibat aktif selama proses pembelajaran.

Pertanyaan-pertanyaan yang diberikan oleh guru dapat merangsang peserta didik untuk berpikir, menemukan jawaban serta menemukan per tayanyaan baru. Hal ini menjadikan proses berpikir pada peserta didik menjadi lebih efektif dan menjadikan proses berpikir peserta didik lebih berkembang. Melalui pertanyaan- 
pertanyaan yang diajukan guru, peserta didik menemukan sendiri konsep yang harus dipahaminya, hal ini menjadikan konsep yang ditemukan menjadi lebih dalam dan dipahami oleh peserta didik. Dalam proses pembelajaran yang dilakukan selama penelitian guru sudah merancang pertanyaan-pertanyaan yang harus dipecahkan oleh peserta didik. Namun tidak hanya pertanyaan dari guru yang menjadi patokan, tetapi peserta didik diperbolehkan untuk membuat pertanyaan dan menjawab pertanyaan mereka sendiri. Hal ini dilakukan untuk memancing proses berpikir peserta didik dan menghindari peserta didik yang pasif di kelas. Pertanyaan-pertanyaan yang dibuat diselesaikan secara diskusi kelompok agar peserta didik dapat bertukar pikiran dan mengembangkan kemampuan berpikirnya. Guru bertindak sebagai penengah dan pemberi penguat jawaban dari peserta didik.

SPPKB menekankan kepada keterlibatan peserta didik secara penuh dalam belajar. Hal ini sesuai dengan hakikat SPPKB yang tidak mengharapkan peserta didik sebagai objek belajar yang hanya duduk mendengarkan penjelasan guru kemudian mencatat untuk dihafalkan. Cara yang demikian bukan saja tidak sesuai dengan hakikat belajar sebagai usaha memperoleh pengalaman, namun juga dapat menghilangkan gairah dan motivasi belajar peserta didik.

Proses pembelajaran dilakuakan berdasarkan langkah-langkah sintaks yang terdapat dalam SPPKB, yaitu tahap pelacakan, tahap konfrontasi, tahap inkuiri, tahap akomodasi, dan tahap transfer. Guru mempersiapkan kondisi peserta didik dengan menyampaikan tujuan pembelajaran yang ingin disampaikan. Kemudian guru mencari tahu seberapa jauh pengetahuan peserta didik tentang materi yang 
akan dipelajari melalui pengalaman-pengalaman yang akan disampaikan oleh peserta didik melalui proses dialog. Selanjutnya guru menyajikan persoalan yang harus dipecahkan peserta didik berdasarkan pengalaman yang diperoleh melalui LDS yang dibagikan kepada peserta didik dengan dibentuk kelompok-kelompok. Guru membimbing peserta didik untuk menemukan jawaban dari persoalan yang diberikan dengan mengembangkan gagasan-gagasan dari peserta didik melalui media yang telah disediakan.

Proses pembelajaran menggunakan SPPKB dibantuu media lembar diskusi siswa (LDS). LDS memuat masalah-masalah yang disertai pertanyaan acuan guna menanamkan konsep atau prinsip bagi peserta didik secara utuh, sistematis, dan diyakini kebenarannya (Heni Oktamalia, 2009). Media LDS dapat berperan sebagai bahan diskusi siswa dalam memecahkan masalah. Peserta didik dengan LDS yang dikerjakannya berusaha menyelesaikan permasalahan dengan menuangkan ide-ide kritis, sehingga membantu dalam proses pembelajaran.

Faktor yang mempengaruhi keberhasilan SPPKB yaitu, dalam proses pembelajaran peserta didik dijadikan sebagai subjek belajar, materi pembelajaran dikaitkan dengan kehidupan nyata, perilaku pembelajaran dibangun atas kesadaran diri, kemampuan didasarkan atas penggalian pengalaman, kemampuan berpikir melalui proses menghubungkan antarapengalaman dengan kenyataan, tindakan dan perilaku dibangun atas kesadaran diri sendiri, pengetahuan yang dimiliki sesuai dengan pengalaman yang dialaminya, serta kriteria keberhasilannya ditentukan oleh proses dan hasil belajar. 
Penerapan SPPKB di dalam pembelajaran dilalui melalui beberapa tahapan, pertama tahap pelacakan. Pada tahap pelacakan peserta didik digali pengalamanpengalaman sebagai pengetahuan awal yang sesuai dengan materi yang akan disampaikan. Kedua, tahap konfrontasi dimana guru menyajikan persoalan yang harus dipecahkan sesuai dengan pengalaman yang diperoleh pada tahap sebelumnya. Tahap ketiga yaitu inkuiri. Pada tahap inkuiri peserta didik berada pada tahap berpikir sesungguhnya yaitu memecahkan masalah yang dihadapi dengan menemukan jawaban dari persoalan yang diberikan dengan mengembangkan gagasan-gagasannya. Tahap selanjutnya yaitu tahap akomodasi, pada tahap akomodasi peserta didik menarik kesimpulan dari hasil pemecahan masalah. Pada tahapan terakhir SPPKB adalah tahap transfer, yaitu tahapan yang mengarahkan peserta didik untuk dapat menggunakan kemampuan berpikirnya pada permasalahan yang baru dan menjadikan siswa menjadi lebih kritis.

Berpikir kritis dapat dikembangkan melalui pembelajaran, salah satunya menggunakan SPPKB. Karena berpikir kritis merupakan proses pemecahan masalah yang terdiri dari kegiatan menganalisis ide atau gagasan ke arah yang lebih spesifik, membedakannya secara nyata, sehingga menghasilkan kesimpulan gagasan yang dapat memecahkan masalah yang dihadapi oleh peseeta didik. Kemampuan berpikir kritis dapat terus terlatih dalam proses pembelajaran SPPKB.

Penelitian ini juga memiliki relevansi dengan penelitian oleh Arif Nurohman, dkk. yang menyatakan bahwa terjadi peningkatan kemampuan berpikir kritis siswa kelas XI IPA 1 Tahun Pelajaran 2013/2014 dalam pemecahan 
masalah fisika menggunakan model Think Talk Write (TTW) berbasis Strategi Pembelajaran Peningkatan Kemampuan Berpikir (SPPKB). Karena SPPKB melatih daya pikir peserta didik dalam penyelesaian masalah yang ditemukan dalam kehidupannya. Peserta didik lebih siap menghadapi setiap persoalan yang disajikan oleh guru, diprioritaskan lebih aktif dalam proses pembelajaran, serta diberi kebebasan untuk mengeksplor kemampua peserta didik dengan berbagai media yang ada.

Berdasarkan uraian diatas, dapat disimpulkan bahwa terdapat pengaruh strategi pembelajaran peningkatan kemampuan berpikir (SPPKB) terhadap kemampuan berpikir kritis biologi peserta didik kelas XI SMA Al-Kautsar Bandar lampung pada materi sistem reproduksi pada manusia.

\section{SIMPULAN DAN SARAN}

Berdasarkan penelitian yang telah dilakukan dan pengolahan hasil penelitian berupa posttest kemampuan berpikir kritis, diperoleh hasil bahwa ${ }_{\text {ang }}>t_{\text {tabel }}$ yaitu, 6,115 > 1,671 maka $\mathrm{H}_{0}$ ditolak dan $\mathrm{H}_{1}$ diterima. Artinya, disimpulkan bahwa terdapat pengaruh yang signifikan strategi pembelajaran peningkatan kemampuan berpikir (SPPKB) terhadap kemampuan berpikir kritis biologi peserta didik kelas XI SMA Al-Kautsar Bandar Lampung.

Berdasarkan penelitian yang telah dilakukan, sebagai bahan rekomendasi dengan mempertimbangkan hasil temuan dilapangan maupun secara teoritis, maka dalam pembelajaran peserta didik harus lebih aktif dan mempersiapkan konsep materi terlebih dahulu, sehingga pada saat proses pembelajaran peserta didik sudah siap dengan pengetahuan awal yang dimiliki agar pemahaman materi lebih 
mudah. Disamping menggunakan metode konvensional guru juga perlu menggunakan strategi pembelajaran peningkatan kemampuan berpikir (SPPKB) dalam proses pembelajaran sebagai trobosan baru yang menekankan pada belajar bermakna dan untuk meningkatkan kemampuan berpikir kritis biologi kedepannya.

\section{DAFTAR PUSTAKA}

Ahmad Jaedun. Metodologi Penelitian Eksperimen. (Makalah yang disampaikan pada Kegiatan In Service I Pelatihan Penulisan Artikel Ilmiah, yang diselenggarakan oleh LPMP, Yogyakarta, 20-23 Juni 2011).

Alec Fisher. Berpikir Kritis. Jakarta: Erlangga, 2008.

Anas Sudijono. Pengantar Evaluasi Pendiddikan (Cet.XII). Jakarta: Rajawali Pers, 2012.

Anisa, Joko, Sulifah. Efektivitas Strategi Pemebelajaran Peningkatan Kemampuan Berpikir (SPPKB) Terhadap Hasil Belajar Dan Aktivitas Siswa Menggunakan Strategi Synargetic Teaching (Pada Mata Pelajaran Biologi di SMP Negeri 10 Jember). Jurnal Pendidikan, Vol. 2, No. 4, 2013.

Arif Nurohman, Ashari, Nurhidayati. Peningkatan Kemampuan Berpikir Kritis dalam Pemecahan Masalah Fisika Menggunakan Model Think Talk Write Berbasis Strategi Pembelajaran Peningkatan Kemampuan Berpikir. Jurnal Penelitian Pendidikan. Radiasi Vol.5 No.1, 2014.

Badan Standar Isi. Standar Isi untuk Pendidikan Dasar dan Menengah.

Bagod Sudjadi, Siti Laila. Biologi Sains Dalam Kehidupan. Jakarta: Yudhistira, 2005.

Bruce Joyce, et. al. Models of Teaching. America: Pearson Education, 2000.

Budiyono, Statistika untuk Penelitian (Cet. III). Surakarta : UNS Press, 2009.

Cucu Suhana. Konsep Strategi Pembelajaran. Bandung: PT Refika Aditama, 2014.

Departemen Agama RI. Al-Qur'an dan Terjemahnya. Jakarta Selatan : PT Pantja Cemerlang, 2010. 
Depdikbud. Perangkat Pembelajaran Kurikulum Tingkat Satuan Pendidikan KTSP SD/MI, SMP/MTs, dan SMA/MA. Balitbang: Depdiknas, 2006.

Dewi Maritalia, Sujono Riyadi. Biologi Reproduksi. Yogyakarta: Pustaka Pelajar, 2012.

Eddyman W Ferial. Biologi Reproduksi. Makasar: PT Gelora Aksara Pratama, 2013.

Elaine B. Jonson. CTL Contextual Teaching \& Learning Menjadikan Kegiatan Belajar-Mengajar Mengasyikkan dan Bermakna (Cet. I). Bandung: Kaifa, 2014.

Emzir. Metode Penelitian Pendidikan Kuantitatif dan Kualitatif (Cet. IV). Jakarta: Rajawali Press, 2010.

H. Surya. Cara Belajar Orang Genius. Jakarta: PT. Elex Media, 2013.

Harun Rasyid dan Mansur. Penelitian Hasil Belajar. Bandung: CV Wacana Prima, 2007.

Henny Oktamalia. Penerapan Problem Based Learning dengan Media LDS Bergambar padaKonsep Pencemaran Lingkungan di SMP Al-Hadi Sukoharjo. Universitas Negri Semarang : Skripsi Jurusan Biologi. 2009.

Husnidar, et. al. Penerapan Model Pembelajaran Berbasis Masalah untuk Meningkatkan Kemampuan Berfikir Kritis dan Disposisi Matematis Siswa. Jurnal Didaktik Matematika. ISSN : 2355 - 4185.

I Nyoman Rida. Strategi Pembelajaran Peningkatan Kemapuan Berpikir (SPPKB) dalam Meningkatkan Prestasi Belajar Pada Mata Pelajaran IPS Tahun Pelajaran 2012/2013. Jurnal Pendidikan, Vol. 6 No.2, 2013.

Indra sahfriana, Wachju Subchan, Suratno. Penerapan Model Pembelajaran Group Investigation (GI) dalam Meningkatkan Kemampuan Berpikir Kritis dan Keterampilan Sosial Siswa dalam Pembelajaran IPA Biologi untuk Materi Ajar Pertumbuhan dan Perkembangan Kelas 8-C Semester Gasal di SMP Negeri 1 Bangil Pasuruan. Jurnal Pendidikan, Pancaran, Vol. 4, No. 2, hal 213-222, Mei 2015.

Iskandar. Penelitian Tindakan Kelas. Jakarta: Referensi, 2012.

Iskandarwassid, Dadang Sunendar. Strategi Pembelajaran Bahasa. Bandung: PT Remaja Rosdakarya, 2008. 
Jamil Suprihatiningrum. Strategi Pembelajaran, Teori dan Aplikasinya. Jogjakarta: Ar-Ruzz Media, 2013.

John W Kimball. Biologi Jilid 2 Edisi Kelima. Jakarta: Erlangga.

Moh Zayyadi. Pengaruh Strategi Pembelajaran Peningkatan Kemapuan Berpikir (SPPKB) Terhadap Hasil Belajar Matematika Siswa SMP 1 Pamekasan. Jurnal Pendidikan Fisika, (Akses 15 Mei 2016).

Moh. Nazir. Metode Penelitian. Bogor: Ghalia Indonesia, 2005.

Muh Tawil, Liliasari. Berfikir Kompleks dan Implementasinya dalam Pembelajaran IPA (Cet. I). Makasar: Badan Penerbit Universitas Negri Makassar, 2013.

Musahir. Panduan Pengajaran Kurikulum Berbasis Kompetensi Mata Pelajaran Biologi. Jakarta: CV. Irfan Putra, 2003.

Neil A Campbell, Recee Mitchell. BIOLOGI Edisi Kelima Jilid 3. Jakarta: Erlangga, 2004.

Nuryani Y Rustaman. et. al. Strategi Belajar Mengajar Biologi Edisi 1 (Cet. I). Jakarta: UPI, 2003.

Prosedur Penelitian Suatu Pendekatan Praktik (Cet. XIIII). Jakarta: Penerbit Reka Cipta, 2010.

Pupuh Fathurrohman, M. Sobry Sutikno. Strategi Belajar Mengajar Melalui Penanaman Konsep Umum dan Konsep Islami. Bandung: Refika Aditama, 2014.

Rostiana Sundayana. Statistika Penelitian Pendidikan (Cet. II). Bandung: ALFABETA, 2015.

S. Margono. Metodologi Penelitian Pendidikan. Rineka Cipta, Jakarta, 2000.

Sri Pujianto. Menjelajah Dunia Biologi untuk kelas XI SMA dan MA 2. Solo: Platinum, 2012.

Statistik untuk Penelitian (Cet. XXIII). Bandung: Alfabeta, 2013.

Sudjana. Metoda Statistika. Tarsito: Bandung, 2005.

Sugiyono. Metode Penelitian Pendekatan Kuantitatif Kualitatif dan R\&D (Cet. X). Bandung: Alfabeta, 2008. 
Suharsimi Arikunto. Dasar-dasar Evaluasi Pendidikan Edisi 2 (Cet. IV). Jakarta: Bumi Aksara, 2015.

Trianto. Model Pembelajaran Terpadu. Jakarta: Bumi Aksara, 2012.

Udin S Winataputra. Strategi Belajar Mengajar IPA. Jakarta: Universitas Terbuka, 2001.

Undang-undang Republik Indonesia. Sistem Pendidikan Nasional No. 20. Jakarta: Sinar Grafika, 2003.

Wahab Jufri. Belajar dan Pembelajaran Sains. Bandung: Pustaka Reka Cipta, 2013.

Wina Sanjaya. Strategi Pembelajaran Beroirentasi Sandar Proses Pendidikan Edisi Pertama (Cet. I). Jakarta: Kencana Prenadamedia Group, 2006.

Winatasasmita Djamhur. Biologi Umum. Jakarta: Universitas Terbuka, 1999.

Wong Solo. "Menggunakan Keterampilan Berpikir untuk Meningkatkan Mutu Pembelajaran" (online), tersedia di: http://supraptojielwongsolo.wordpress.com/2008/06/13/menggunakanketerampilan-berpikir-untuk-meningkatkan-mutu-pembelajaran. $\mathrm{htm} \quad(06$ Maret 2016).

Yesi Agustin. Strategi Pembelajaran Peningkatan Kemampuan Berpikir (SPPKB) dalam Pembelajaran Pemahaman Cerita Rakyat Musi Banyuasin Siswa Kelas X Sekolah Menengah Atas Negeri 9 Palembang. Jurnal Pendidikan, (Akses: 13 Mei 2016). 